\title{
Swahili Learners' Views on the Need for a Monolingual Swahili Pedagogical Dictionary
}

\author{
James S. Mdee, University of Dar es Salaam, \\ Tanzania
}

\begin{abstract}
Swahili is a second language to many East and Central Africans, and a foreign language to its learners from Europe, America, Asia and other parts of Africa as well. Yet it lacks a monolingual Swahili learners' dictionary specifically designed for them.

The paper discusses the need for a monolingual Swahili pedagogical dictionary which helps the foreigner learn the language. A pedagogical dictionary is oriented towards encoding Swahili, hence it is logical that some Swahili grammatical aspects are incorporated into the dictionary: noun class system, concordial agreements, the morphology of the language, etc.

The paper is based on the premise that dictionary writing should be based on the users' needs which can be found out by consulting them through research.

A research conducted in language schools where Swahili is taught as a foreign language covered eight items which the subjects were asked to respond to. These included: dictionaries they use, selection of a word list for a Swahili dictionary, treatment of verb derivatives, information categories to be entered in a dictionary and description of meaning.

The research revealed the information categories that Swahili dictionary users would like to see included in a dictionary designed for them. It also showed that dictionary users know their needs and that they are very resourceful and useful to the lexicographer. They can help the dictionary maker to compile a dictionary tailored to their needs and wishes.
\end{abstract}

Keywords: CONCORDIAL AGREEMENTS, DESCRIPTION OF MEANING, DICTIONARY USERS, INFORMATION CATEGORIES, LEXICOGRAPHY, MONOLINGUAL LEARNERS' DICTIONARY, MORPHOLOGY, NOUN CLASS SYSTEM, PEDAGOGICAL DICTIONARY, SECOND LANGUAGE, SWAHILI, VERB DERIVATIVES

\footnotetext{
Abstrait: Besoin d'un dictionnaire pédagogique du swahili selon l'avis des étudiants du swahili. Le swahili est une seconde langue pour beaucoup d'Africains de l'Afrique de l'Est et de l'Afrique Centrale. Aussi est-ce une langue étrangère pour des étudiants de l'Europe, de l'Amérique, de l'Asie et pour les autres parties de l'Afrique. Mais il manque un dictionnaire swahili monolingue pour les étudiants de la langue.

Ce papier discute le besoin d'un dictionnaire pédagogique monolingue qui aidera l'étranger à apprendre la langue. Le but d'un tel dictionnaire pédagogique est d'encoder le swahili, d'où le besoin d'incorporer des aspects grammaticaux du swahili dans un tel dictionnaire, comme le système de noms, les accords grammaticaux, la morphologie de la langue, etc.
} 
Le papier se base sur la prémisse que la compilation d'un dictionnaire se fonde sur les besoins de l'usager du dictionnaire, ces besoins étant révélés par des recherches faites en consultation avec les usagers.

Des recherches sur huit points ont été faites dans les écoles de langue où le swahili est enseigné comme langue étrangère. Ceux-là comprennent: les dictionnaires qu'ils emploient, la sélection d'une liste de noms pour un dictionnaire swahili, le traitement des dérivés verbaux, les catégories d'information requises pour un tel dictionnaire et une description des sens.

La recherche ont révéle, d'une part, les catégories d'information que les usagers d'un dictionnaire swahili voudraient voir incluses dans un dictionnaire désigné pour leur usage, et, d'autre part, que les usagers des dictionnaires connaissent bien leurs besoins et qu'ils sont très ingénieux et très utiles au lexicographe. Ils peuvent aider le lexicographe à compiler un dictionnaire taillé à leurs besoins et désirs.

Mots-Clefs: ACCORDS GRAMMATICAUX, CATéGORIES D'INFORMATION, DéRIVés VERBAUX, DESCRIPTION DES SENS, DICTIONNAIRE MONOLINGUE POUR LES ÉTUDIANTS, DICTIONNAIRE PéDAGOGIQUE, LEXICOGRAPHIE, MORPHOLOGIE DE LA LANGUE, SECONDE LANGUE, SWAHILI, SYSTèME DE NOMS, USAGERS DES DICTIONNAIRES

\section{Definition of Keywords used in this Paper}

1. An agglutinative language is a language whose words contain a linear sequence of morphs, e.g.

$\begin{array}{llll}\text { a- } & \text { na- } & \text { soma } & \text { (anasoma) } \\ \text { '(s)he' } & \begin{array}{l}\text { present } \\ \text { tense }\end{array} & \text { 'read' } & \\ & \text { marker } & \end{array}$

'(s)he is reading'

2. A derivative is a word formed by adding prefixes and / or suffixes to a root morpheme, e.g.

$\begin{aligned} & \text { chek-esh-a } \\ & \text { 'cause to laugh' }\end{aligned} \quad \begin{aligned} & \text { chek-a } \\ & \text { 'laugh' }\end{aligned}$
m-chek-esh-aji
'One who makes
others laugh'


3. A geographical variety is a dialect of a language which is used by people of a given geographical area.

4. An illustrative example sentence is an example sentence showing the words which always appear together with the entry word in language usage.

5. An information category is a type of information rendered in a dictionary, e.g. pronunciation, word class label, usage notes, meaning, etc.

6. IPA Phonetic symbols are phonetic transcriptions of phonemes as recommended by the International Phonetic Association.

7. Lexicographic needs is the dictionary information that dictionary users would want to be included in a dictionary they use because it is the information they usually look up.

8. A noun class is a group of nouns which has common morphological and / or syntactic characteristics, e.g.

\begin{tabular}{|c|c|c|}
\hline$\frac{\text { m-toto; }}{\text { 'child' }}$ & $\frac{\text { m.kulim }}{\text { 'farmer' }}$ & \\
\hline$\frac{\text { m-toto }}{\text { child }}$ & $\begin{array}{l}\text { m-dogo } \\
\text { small }\end{array}$ & $\begin{array}{l}\text { a-nacheza } \\
\text { (s)he is playing' }\end{array}$ \\
\hline$\frac{\text { m-kulim }}{\text { 'farmer }}$ & $\frac{\text { m-dogo }}{\text { small }}$ & $\begin{array}{l}\text { a-nacheza } \\
\text { (s)he is playing' }\end{array}$ \\
\hline
\end{tabular}

9. Respelling a word is showing the letters of a word to indicate pronunciation.

10. A social variety is a language variety commonly used by a social group of a linguistic community.

11. The standard spelling is the accepted spelling of a word.

12. A stressed syllable is a syllable of a word where stress is put.

13. A subject prefix is the first prefix attached to a verb which represents the subject in the predicator, e.g.

John a-nasoma 'John he is reading'

It is also known as a verbal concord because it appears in a verb. 
14. A syllabic nasal is a nasal with syllabic feature. A nasal with this feature is usually followed by a consonant instead of a vowel, in which case it becomes a syllable; e.g., maji 'water' has two syllables, ma + ji. The nasal $\underline{m}$ plus the vowel a form a normal syllable. mji 'town' has two syllables as well, $m+\ddot{j}$. The nasal $\underline{m}$ does not have a vowel, but because it is followed by the consonant $j$, it acquires a syllabic feature $(+u)$ and is pronounced as "muji" although it is written mji.

15. A variant spelling is an alternative spelling of a word which is contrasted with the standard or accepted spelling of the same word, e.g. benki, bengi 'bank'.

16. A word class label is a grammatical category marker rendered to a word to indicate its grammatical category.

17. A word list is a list of words selected for a dictionary.

\section{Introduction}

The aim of this paper is to present and discuss research findings of a lexicographic survey conducted at language schools teaching Swahili to foreigners resident in Tanzania.

In this paper we shall highlight and discuss the following:

a) a theoretical framework for a monolingual learners' dictionary

b) statement of the problem

c) objective of the research

d) research subjects

e) research method

f) some aspects of Swahili grammar

g) research coverage

h) research findings and description

i) analysis of the findings

j) conclusion

\section{A theoretical framework}

"Dictionaries should be designed with a special set of users in mind and for their specific needs."

(Householder and Saporta 1962: 279)

This statement is valid today as it was in 1962 at the Bloomington Lexicography Conference. It re-emphasizes the importance of understanding the needs 
of the dictionary user before writing one.

Barnhart's paper, which influenced the above quoted conclusion, was based on research he conducted (1955) and in which he tried to establish the usefulness of various information categories. In this research he found that students looked for specific information whenever they consulted a dictionary.

Since then, more studies have been conducted to find out the user's opinions about the dictionary he uses (Quirk 1973), the activities for which a dictionary is used (Tomaszczyk 1979), the value of the dictionary in language acquisition (Bejoint 1981), the way information is obtained from a dictionary (Tono 1992), etc.

The essence of these studies is the realization that dictionary makers have not sufficiently taken note of the needs of the dictionary users. Dictionary makers have been accused of assuming the right to decide what is good or not good for the users without consulting them.

In spite of the numerous studies already done, the researchers do not seem to have influenced dictionary making to focus on the user's needs, hence Stein's (1984: 4) observation:

"Dictionaries are obviously written for their users. We therefore need more research on the dictionary user, his needs, his expectation and his prejudices."

From the commercial point of view, a dictionary that meets the user's needs will definitely sell, hence the importance of dictionary publishers to compile and publish dictionaries that meet this condition. Underscoring this, Barnhart (1962: 161) observes: "It is the function of a popular dictionary to answer the questions that the user of the dictionary asks, and dictionaries on the commercial market will be successful in proportion to the extent to which they answer these questions of the buyer." The shortcomings of lexicographic research notwithstanding (cf. Hatheral 1984: 183), 1 research on the dictionary user by the dictionary writer is very important because it is the best method to establish what the user needs. It is with this understanding that this research was conducted.

A dictionary is used for decoding and encoding a language. ${ }^{2}$ Both a native speaker and a language learner use a dictionary for comprehension, i.e. for decoding purposes, but a language learner uses it for production as well, i.e. for encoding the target language. Although dictionaries contain much similar

$1 \quad$ Hatheral (1984: 183) doubts whether research subjects who fill out questionnaires actually state their views (which they believe in) or give the information which they think the researcher wants.

2 A dictionary is used for decoding when one uses it to get the meaning of words in order to comprehend a passage in which the words are used. It is used for encoding when one uses it to guide him / her to produce sentences using the words at his disposal. 
lexicographic information, dictionaries for encoding a language have additional and sometimes detailed information that helps the user to use the language more productively.

\section{Statement of the problem}

Swahili is a second language to many East Africans and it is taught as a foreign language in some universities in Europe, the U.S.A., Asia and in Africa. In Tanzania there are about ten language schools which teach Swahili to foreigners. Moreover, Swahili has been adopted as one of the conference languages by UNESCO and the OAU although this has not yet been realized. The integration of Eastern, Central and Southern African countries into an economic community such as SADC will no doubt motivate more people in this region to learn Swahili.

In spite of all this, Swahili does not have a monolingual dictionary specifically designed for Swahili learners. The existing monolingual dictionaries are designed for the native Swahili speakers, hence are oriented towards decoding the language (cf. Johnson 1935; Bakhressa 1992).

In the light of this, we think there is need to compile a Swahili pedagogical dictionary that will help its user to encode the language.

But because a dictionary is written for a specific set of users with specific needs, we felt that it was imperative to consult them and in order to establish their dictionary needs before attempting to compile one.

\section{Objective of the research}

The objective of the research was to collect lexicographic data from Swahili learners. This is the information which language learners would like to be included in a Swahili learners' dictionary, e.g. spelling, pronunciation, some grammatical information, meaning, etc.

\section{Research subjects}

The survey was conducted at six language schools which teach Swahili to foreigners. One hundred and eleven subjects were consulted. These were mainly expatriates who came to work in Tanzania (medical doctors, teachers, nurses, social workers, agriculturalists, etc.), missionaries (priests and sisters), and university students. With exception of the students who came to Tanzania after learning Swahili at their home universities, the other groups learnt Swahili for the first time in Tanzania. The Swahili learners came from America (North, Central and Latin America), Europe, Asia, and Africa. 


\section{Research method}

A questionnaire was given to all the subjects. Three types of questions were asked:

(i) multiple choice questions

(ii) filling up blanks questions

(iii) descriptive questions

Before we present the research findings, let's examine briefly some aspects of Swahili grammar.

\section{Some aspects of Swahili grammar}

Swahili is an agglutinated language. Its nouns are divided into eight or nine classes depending on how one counts or classifies them. (Cf. Ashton 1944, TET 1988, Mdee 1988.) Every noun class has a singular and plural affix which are specific to the noun class (henceforth NC) and are prefixed to the root of the nouns of that class. The prefixes of these nouns are the class markers.

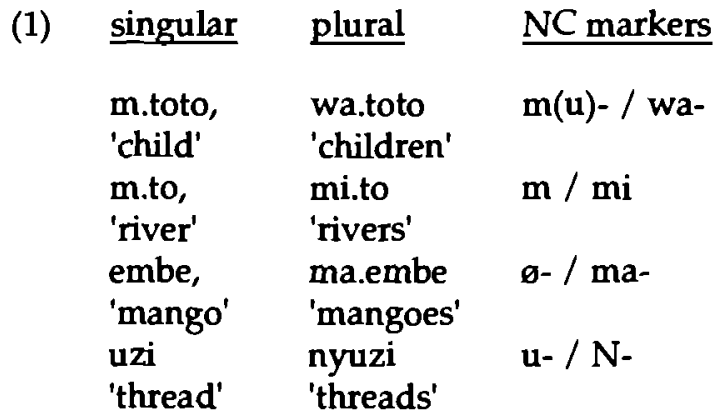

The Swahili noun determines the concords for its qualifier and verb in the predicate, hence every NC has concords specific to the NC.

(2)

\begin{tabular}{|c|c|c|c|c|}
\hline $\begin{array}{l}\text { mtoto } \\
\text { 'child } \\
\text { mtoto } \\
\text { 'child } \\
\text {-embe } \\
\text { 'mango } \\
\text { embe } \\
\text { 'mango }\end{array}$ & $\begin{array}{l}\text { mzzuri } \\
\text { good' } \\
\text { analala } \\
\text { he is sleep(ing)' } \\
\text {-zuri } \\
\text { good' } \\
\text { li.meoza } \\
\text { it has rotten' }\end{array}$ & ; & $\begin{array}{l}\text { kiti } \\
\text { 'chair } \\
\text { kiti } \\
\text { 'chair } \\
\text { nyumba } \\
\text { 'house } \\
\text { nyumba } \\
\text { 'house }\end{array}$ & $\begin{array}{l}\text { kizuri } \\
\text { good' } \\
\text { kimeanguka } \\
\text { it has fallen' } \\
\text { nzuri } \\
\text { good' } \\
\text { imeanguka } \\
\text { it has fallen' }\end{array}$ \\
\hline
\end{tabular}

Nouns and verbs are generated from verbs through a derivational process. 
$\begin{array}{llll}\text { (3) imb.a } & > & \begin{array}{l}\text { imb.ia } \\ \text { imb.isha }\end{array} \text { v. 'sing for' } \\ \text { imb.wa } & \text { v. 'sung by' } & \text { 'make one to sing' } \\ \text { imb.ana } & \text { v. 'sing to one another' } \\ \text { ji.imb.ia } & \text { v. 'sing to oneself } \\ \text { w.imbo } & \text { n. 'song' } \\ \text { ny.imb.o } & \text { n. 'songs' } \\ \text { u.imb.a.ji } & \text { n. '(style of) singing' }\end{array}$

Pronunciation of Swahili words is rule-governed. The syllable always ends with a vowel and the stress is usually put on the penultimate syllable. Word formation allows for deletion, addition and substitution of affixes.

(4)

$\begin{array}{lll}\text { cheza } & \text { 'play' } & \text { v. } \\ \text { chez.esh.a } & \text { 'cause to play' } & \text { v. } \\ \text { m.chez.o } & \text { 'play' } & \text { n. } \\ \text { m.chez.a.ji } & \text { 'player' } & \text { n. }\end{array}$

\section{Research coverage}

The questionnaire covered the following eight items:

a) Level of language competence attained.

b) Dictionaries being used.

c) Selection of a word list for a Swahili pedagogical dictionary.

d) Status of the words to be selected (social and geographical varieties / sociolects and dialects).

e) Grammatical information that learners would like to be included in a dictionary article.

f) Presentation of verb derivatives: how they should be entered in the dictionary.

g) Hierarchy of preference of information categories in a Swahili dictionary.

h) Description of meaning.

The research subjects were also asked to provide reasons for the answers they had given.

\subsection{Research findings and description}

The responses were computed to find out the percentage of the scores for each of the questions asked. 


\subsection{Level of language competence attained}

All the 111 subjects had a certain degree of mastery of Swahili, ranging from beginners, $55 \%$ of the subjects, intermediate level, $35 \%$ of the subjects, and advanced level, $9 \%$ of the subjects. The research was conducted during the last week of a three or four months basic Swahili course. This information was necessary in order to ascertain that the learners had been exposed to the Swahili grammar and realized its intricacies. In so doing the subjects as learners of Swahili would be in a position to appreciate the questions on Swahili grammar and the areas of grammar that Swahili learners find difficult to comprehend and / or remember. Such information would be put in a dictionary for quick reference.

\subsection{Dictionaries consulted}

Since the major objective was to consult Swahili learners in order to find out their lexicographic needs, it was imperative to know if they used dictionaries in the first place. So the first question wanted them to list Swahili dictionaries they used. The results showed that the majority had used a dictionary for decoding as shown in (5).

(5) $81 \%$ of the 111 Swahili learners used

Swahili-English Dictionary

or

Swahili-German Dictionary

or

Swahili-Swedish Dictionary

$63 \%$ of the learners used

English-Swahili Dictionary

or

German-Swahili Dictionary

or

Swedish-Swahili Dictionary

$10 \%$ of the subjects used

Swahili-Swahili Dictionary

$8 \%$ of the learners consulted no Swahili dictionary up to

the time of research.

The high percentage of Swahili learners using dictionaries is a testimony to the importance of a dictionary in language learning, especially in decoding. This is 
reflected by the $81 \%$ of the learners who used Swahili-English or Swahili-Swedish or Swahili-German dictionaries. The use of a monolingual Swahili dictionary, although by a small minority $(10 \%)$, is an indication that some intermediate and advanced level learners do consult it.

\subsection{Selection of a word list for a dictionary}

Bearing in mind the fact that the language learners work in Tanzania and Kenya where different varieties of Swahili ${ }^{3}$ are spoken, they were asked to state the source from which the word list could be drawn. The responses were:

(6)

$\begin{array}{lr}\text { East African standard Swahili } & 54 \% \\ \text { All Swahili dialects } & 7 \% \\ \text { East African and Zairean standard Swahili } & 19 \%\end{array}$

Reasons given as to why the East African standard Swahili was preferred include:

a) The East African standard variety is widely known. Learners should not be confused with other dialects.

b) Many dialects in a dictionary will make the dictionary complex, confusing and cause code mixing and code switching.

c) A learners' dictionary should be restricted to the most basic variety.

\subsection{Status of the words selected for the dictionary}

A standard dictionary reflects the norm which is the accepted variety. A dictionary may enter a lexeme in its standard spelling with or without its variant spelling. With regard to the status of the words to be entered in a Swahili dictionary, the subjects gave the following preferences:

$$
\begin{aligned}
& \text { Standard and variant spellings } \\
& \text { Standard spelling only }
\end{aligned}
$$

$46 \%$

$35 \%$

The reasons given for preferring both the standard and the variant spellings were: 
a) They help learners to appreciate and understand literary works of authors of different dialects.

b) They enable the learner to know the most commonly used slang and dialectal forms, e.g. school or street Swahili.

The respondents who preferred only the standard orthography of a lexeme to be entered in the dictionary gave the following reasons:

a) This is the spelling that users will encounter in writings.

b) Different spellings for a headword will confuse the learners.

c) Slang is shortlived, it is better to get the preferred spellings.

d) Avoid alternative spellings because some of them are influenced by ethnic languages.

e) The objective of a Swahili dictionary is to teach the standard Swahili.

\subsection{Pronunciation guide in a Swahili dictionary}

On the question whether a Swahili learners' dictionary needs a pronunciation guide, the responses were:

(8) Show how to pronounce cumbersome words $47 \%$

Show how every word is pronounced

Do not show how words are pronounced

Reasons given for supporting the proposal of showing a pronunciation guide only to words which are cumbersome to pronounce were:

a) Swahili has clear rules of pronunciation.

b) Swahili words are not difficult to pronounce once vowels are known except for long words.

Words which are difficult to pronounce are usually those with nasal compounds.

On the preferred system of presenting phonetic spelling to be used in a Swahili dictionary for the words that need a pronunciation guide, the responses indicated were:

(9) Phonetic symbols of the IPA

$52 \%$

Respelling of the word 


\subsection{Grammatical information on an entry word}

Six aspects of grammatical information for an entry word were tested and the scores were as follows:

$\begin{array}{ll}\text { Word class label } & 78 \% \\ \text { Noun class marker } & 76 \% \\ \text { Stressed syllable } & 43 \% \\ \text { Subject prefix of a verb (verbal concord) } & 49 \% \\ \text { Syllables of a word } & 27 \% \\ \text { Syllabic nasal of a word } & 16 \%\end{array}$

\subsection{Word formation}

\subsubsection{Derivatives}

Swahili verbs: verb derivatives and nominal deverbatives can be derived as in (11) below:

$$
\begin{array}{lllll}
\begin{array}{l}
\text { cheza }> \\
\text { 'play' }
\end{array} & \begin{array}{l}
\text { chezea, } \\
\text { 'play for' }
\end{array} & \begin{array}{l}
\text { chezesha, } \\
\text { 'cause to } \\
\text { play' }
\end{array} & \begin{array}{l}
\text { chezeka, } \\
\text { 'be in a } \\
\text { state of } \\
\text { being played' }
\end{array} & \begin{array}{l}
\text { chezwa. } \\
\text { 'be played' }
\end{array} \\
& \begin{array}{l}
\text { mchezo } \\
\text { 'play' }
\end{array} & \begin{array}{l}
\text { mchezaji } \\
\text { 'player' }
\end{array} & \begin{array}{l}
\text { uchezaji } \\
\text { 'style of playing' }
\end{array}
\end{array}
$$

From the verb cheza, more verbs have been derived: chezesha, chezea, chezeka and chezwa. Nouns have also been derived from the same verb: mchezo, mchezaji and uchezaji.

The treatment of verb derivatives eludes many dictionary makers. When asked to state the method of entering verb derivatives in a dictionary they preferred them to be entered as:

(12) Headwords or run-ons and be defined $55 \%$ Undefined run-ons $6 \%$ Undefined derivational suffixes $\quad 8 \%$

\subsubsection{Affixes}

Affixes are linguistic units which maybe entered in a dictionary although they are not lexical items. Proposals for treating affixes had the following scores: 
(13) Put all affixes in the appendix

$55 \%$

Indicate word formation pattern

$31 \%$

Enter common affixes as headword

$17 \%$

\subsection{Treatment of nouns and verbs}

\subsubsection{Nouns}

On the treatment of nouns, the subjects were asked to recommend the method of indicating the plural forms or inflections in a dictionary. $42 \%$ of the subjects wanted the irregular plural forms to be entered as headwords and the plural prefixes of regular nouns to be put beside the singular noun; $25 \%$ preferred the irregular plural forms as well as the plural prefixes to be juxtaposed to the singular noun, and $15 \%$ wanted all plural forms to be entered as headwords.

\subsubsection{Verbs}

Processing the verb entails rendering the word class label and indicating the complements of a verb. $32 \%$ of the subjects wanted the word class label and a grammatical pattern of a verb complement to be rendered as in (14) below:

$\begin{array}{ll}\text { taka v. a) }[+ \text { obj] } & \begin{array}{l}\text { taka chakula } \\ \text { 'want food' } \\ \text { 'want' } \\ \text { taka kula chakula } \\ \text { 'want to eat food' } \\ \text { taka kulala }\end{array} \\ \begin{array}{ll}\text { c) }[+ \text { twu + verb + obj } \\ \text { 'want to sleep' }\end{array}\end{array}$

25\% wanted only the word class and sub word class labels to be marked such as v. (verb) or v.t. (verb transitive) or v.i. (verb intransitive).

8.10 Hierarchy of preference of information categories in a Swahili dictionary

The subjects were given eleven information categories and asked to mark: $1=$ very important, $2=$ less important, and $3=$ not important, to indicate the importance of the information given. 
(15)

$\begin{array}{ll}\text { Standard spelling of a word } & \mathbf{8 3} \% \\ \text { Grammatical category marker } & \mathbf{7 0 \%} \\ \text { Subgrammatical category marker } & \\ \quad \text { such as NC markers } & 54 \% \\ \text { Plural forms and prefixes of nouns } & 54 \% \\ \text { A sketch Swahili grammar } & 53 \% \\ \text { Collocations } & 43 \% \\ \text { nlustrative example sentences } & 43 \% \\ \text { Usage restrictions } & 33 \% \\ \text { Pronunciation guide } & 30 \% \\ \text { Stressed syllable } & 19 \% \\ \text { Syllabic nasal } & 11 \%\end{array}$

\subsection{Description of meaning of a headword}

The methods of explaining the meaning of a word, scored points as follows:
A descriptive definition and a synonym
$52 \%$
A descriptive definition (phrase or clause)
$25 \%$
A one-word paraphrase (synonym)
$10 \%$

\section{Critical analysis of the data}

An examination of the subjects' responses reveals that language users can help to shape the dictionary that is designed for them if they are consulted.

Looking at the dictionaries they used, we find that language learners, especially beginners, need a dictionary for decoding purposes most. As they enter intermediate and advanced levels they need a dictionary for encoding Swahili, a dictionary that will expose them to the target language whereby they will read a lexical item and its definition in the same language. This is a monolingual leamers' dictionary which will encourage the learner to start thinking in Swahili.

A Swahili learners' dictionary should contain words that the learners need. Words from dialects other than the norm are not used by the majority of the dictionary users, hence need not be entered. Words from the Zairean norm are hardly used outside that country, hence do not qualify either. Only words from the East African norm should be entered because it is the most widely used in East Africa, hence the high score for the East African standard Swahili. Care should be taken when entering words with variant spellings. In a Swahili learners' dictionary they should be kept to a minimum. In fact, only one variant, the one with the highest occurrence, should be allowed as alternative to the standard orthography. 
There is no doubt that Swahili is in most cases pronounced as it is written, hence in principle it needs no pronunciation guide. However, items which are not easy to articulate should be marked. Whereas it is not necessary to mark stress and intonation, it may be helpful to indicate syllabic feature of nasal in order to differentiate a compound nasal pronounced as a unit, from a syllabic nasal followed by a consonant, which have the same form graphically.

$$
\begin{array}{ll}
\text { compound nasal } & \text { syllabic nasal } \\
\underline{m b} \text { as in mbaya } & \mathrm{mb} \text { as in mbaya }
\end{array}
$$

A respelling system of indicating pronunciation seems to be familiar with the subjects because this is the method commonly used in English dictionaries. An IPA phonetic symbol is more appropriate because it helps one to reproduce sounds that are not in one's first language, and may not be articulated correctly by respelling.

$$
\text { ng'ongo / nongo / nyama / nums / }
$$

Pronunciation of these words cannot be reproduced correctly by respelling from the English language point of view because, whereas the language has $/ \mathrm{n} /$, this symbol represents the Swahili /ng/. The Swahili / $\mathrm{ng} /$ is lacking in the English language.

A word class label has no lexicographic significance in the dictionary (because a word class can be detected from the definition of the headword) although it has become a lexicographic practice to give such labels. The need for marking a noun class is significant in a Swahili dictionary because the noun influences the selection of an adjectival concord (AC), a verbal concord (VC), and a demonstrative concord (DC). These grammatical aspects are important for a grammatically correct sentence.

$\begin{array}{llll}\text { (19) } \begin{array}{ll}\text { DC } \\ \text { Huyu } \\ \text { 'This }\end{array} & \begin{array}{l}\text { mtoto } \\ \text { child }\end{array} & \begin{array}{l}\text { AC } \\ \text { kind }\end{array} & \begin{array}{l}\text { VC } \\ \text { analala } \\ \text { he is sleep(ing)' }\end{array} \\ \begin{array}{llll}\text { Huu } \\ \text { 'This }\end{array} & \begin{array}{l}\text { mti } \\ \text { tree }\end{array} & \begin{array}{l}\text { mfupi } \\ \text { short }\end{array} & \begin{array}{l}\text { unakauka } \\ \text { it is dry(ing)' }\end{array} \\ \begin{array}{l}\text { Hili } \\ \text { 'This }\end{array} & \begin{array}{l}\text {-embe } \\ \text { mango }\end{array} & \begin{array}{l}\text {-bivu } \\ \text { ripe }\end{array} & \begin{array}{l}\text { limeoza } \\ \text { it has rotted' }\end{array} \\ \text { Hii } & \text { kalamu } & \text {-fupi } & \text { imeanguka } \\ \text { 'This } & \text { pen } & \text { short } & \text { it has fallen' }\end{array}$


Usage has been the main criterion for selecting lexical items of a dictionary, hence the same criterion should also apply to derivatives. Only derivatives with high occurrence need to be selected. These should be treated as full lexical items and entered either as headwords or run-ons and be defined.

It is important that a learners' dictionary does not enter affixes to represent lexemes because they can create retrieval problems. When the user looks up a word he may not be able to find it because only a part of it is entered and one cannot associate the given element and the whole word.

The responses to the treatment of affixes were not impressive. See (13) above. This is because affixes are linguistic aspects that the subjects were not familiar with. Therefore, they had no interest to respond to the question. In spite of this, affixes should be entered in the dictionary. Its appropriate place is in the appendix as back matter.

The formation of plural nouns is rule-governed. They are based on the noun class. Nouns which undergo phonological change or deletion when the plural inflection is prefixed to the singular nouns have to be entered as headwords.

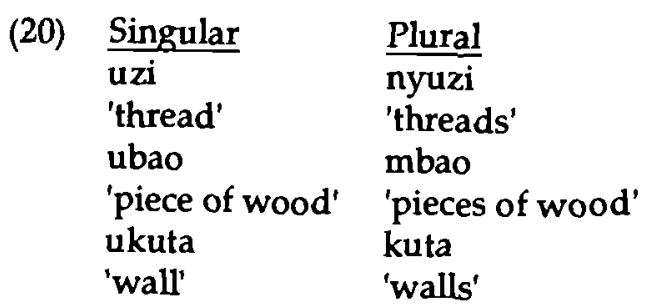

For other nouns, plural inflections should be juxtaposed to the singular nouns. This will mean that a singular prefix is replaced by a plural prefix to form a plural noun. A singular noun with a zero prefix will have the plural prefix attached to the stem.

$\begin{array}{ll}\text { m.chezaji, } & \text { wa- } \\ \text { 'player' } & \\ \text { m.ti, } & \text { mi- } \\ \text { 'tree' } & \\ \text { ki.tu, } & \text { vi- } \\ \text { 'thing' } & \\ \text { embe, } & \text { ma- }\end{array}$

The verb phrase pattern showing the obligatory elements complementing the verb is necessary for a learners' dictionary because it guides the users to generate their own sentences. See (23) below.

The description of meaning of a lexeme is complete and self-contained if it is stated unambiguously in a descriptive paraphrase and if need be, it may be 
complemented by a synonym. A descriptive definition states the semantic or grammatical contexts of the lexeme which cannot be stated fully by a synonym alone, especially if it is polysemous. It is therefore essential for the headwords of a monolingual dictionary to be defined in a descriptive form.

On examining the information categories, it is important to note the significance the learners attached to the standard spelling of headwords vis-à-vis the variant spellings. It is interesting to note also the importance of the $\mathrm{NC}$, plural inflections and a brief Swahili grammar. Surprisingly, example sentences and collocations have not been regarded as important information (cf. 15 above).

The grammatical information that needs to be rendered to the noun and the verb in a Swahili dictionary is as shown in (22) and (23) below respectively.

\begin{tabular}{|c|c|c|c|}
\hline & & $\frac{\text { Plural }}{\text { Prefix }}$ & $\frac{\text { Verbal Concord }}{\text { Sing } \mathrm{Pl}}$ \\
\hline $\begin{array}{l}\text { mtu } \\
\text { 'person' }\end{array}$ & n. & wa- & $\overline{(a-, w a-)}$ \\
\hline $\begin{array}{l}\text { mti } \\
\text { 'tree' }\end{array}$ & n. & mi- & $(u-, i-)$ \\
\hline $\begin{array}{l}\text { chungwa } \\
\text { 'orange' }\end{array}$ & n. & ma- & (li-, ya-) \\
\hline $\begin{array}{l}\text { nyumba } \\
\text { 'house' }\end{array}$ & n. & - & $(\mathrm{i}-, \mathrm{zi}-)$ \\
\hline $\begin{array}{l}\text { uji } \\
\text { 'porridge' }\end{array}$ & n. & - & $(\mathbf{u}-)$ \\
\hline $\begin{array}{l}\text { maziwa } \\
\text { 'milk' }\end{array}$ & n. & - & (ya-) \\
\hline
\end{tabular}

(23)

\begin{tabular}{|c|c|c|c|}
\hline pika & v. & {$[+o b j]$} & pika chakula \\
\hline jaribu & v. & (1) $[+o b j]$ & jaribu mtihani \\
\hline & & (2) $[+k u+$ verb $+o b j]$ & $\begin{array}{l}\text { attempt examination' } \\
\text { jaribu kufanya mtihani } \\
\text { 'attempt to do examination }\end{array}$ \\
\hline la & v. & [ - obj] & $\begin{array}{l}\text { lala kitandani } \\
\text { 'sleep on a bed' }\end{array}$ \\
\hline
\end{tabular}

Note that the dash at nyumba and uji denotes that the nouns have no plural forms. The symbols + and - are used to indicate the transitivity of a verb [+obj] means the verb takes an object, i.e. it is a transitive verb; [-obj] means the verb is intransitive. 


\section{Conclusion}

The significance of a Swahili monolingual dictionary for encoding and decoding Swahili needs not be overemphasized. However, because foreigners learn Swahili for official usage, and communication with a wide spectrum of the speech community, the language they need is the accepted norm. As a language, Swahili has grammatical aspects which are specific to itself (or other Bantu languages). These aspects need to be highlighted in the dictionary. They include the noun class, pronunciation, plural forms of nouns, and the treatment of the verb and the verb derivatives.

Despite the shortcoming of using questionnaires to solicit information from the subjects, such as the subjects giving information that they don't believe in, but which they think the researcher wants (cf. Hatheral 1984), the research was open-ended and has nonetheless revealed the opinion of the Swahili learners.

\section{References}

Ashton, E.O. 1944. Swahili Grammar. London: Longman.

Bakhressa, S.K 1992. Kamusi ya Maana na Matumizi. Nairobi: OUP.

Barnhart, C.L. 1962. Problems in Editing Commercial Monolingual Dictionaries. Householder, Fred W. and Sol Saporta (Eds.). 1962: 161-181.

Bejoint, Henri. 1981. The Foreign Student's Use of Monolingual English Dictionaries: A Study of Language Needs and Reference Skills. Cowie, A.P. (Ed.). 1981: 207-222.

Cowie, A.P. (Ed.). 1981. Lexicography and Its Pedagogic Applications. Applied Linguistics 2(3): 201-203.

Cowie, A.P. (Ed.). 1987. The Dictionary and the Language Leamer. Tübingen: Max Niemeyer Verlag.

Hartmann, R.R.K 1987. Four Perspectives on Dictionary Use: A Critical Review of Research Methods. Cowie, A.P. (Ed.). 1987: 11-28.

Hartmann, R.R.K. (Ed.). 1984. LEXeter ' 83 Proceedings. Papers from the International Conference on Lexicography at Exeter, 9-12 September 1983. Lexicographica, Series Maior 1. Tübingen: Max Niemeyer Verlag.

Hatheral, G. 1984. Studying Dictionary Use: Some Findings and Proposals. Hartmann, R.K.K. (Ed.). 1984: 183-189.

Householder, Fred W. and Sol Saporta (Eds.). 1962. Problems in Lexicography. Bloomington: Indiana University / The Hague: Mouton .

Johnson, F. 1935. Kamusi ya Kiswahili, yaani Kitabu cha Maneno ya Kiswahili. London: Sheldon Press.

McDavid, Raven I. Jr. and Audrey R. Duckert (Eds.). 1973. Lexicography in English. New York: New York Academy of Sciences.

Mdee, J.S. 1988. Sarufi ya Kiswahili. Dar es Salaam: Education Services Center. 
Quirk, R. 1973. The Social Impact of Dictionaries in the U.K. McDavid, Raven I. Jr. and Audrey R. Duckert (Eds.). 1973: 76-88.

Stein, G. 1984. Towards a Theory of Lexicography: Principles and/vs. Practice in Modem English Dictionaries. Hartmann, R.R.K. (Ed.). 1984: 124-130.

Taasisi ya Elimu, Tanzania (TET). 1988. Kistuahili Sekondari. Dar es Salaam.

TET. 1988 = Taasisi ya Elimu, Tanzania (TET). 1988.

Tomaszczyk, Jerzy. 1979. Dictionaries: Users and Uses. Glottodidactica 12: 103-120.

Tono, Y. 1992. The Effect of Menus on EFL Learners' Look-up Processes. Lexikos 2: 230-253. 